Int. J. Electrochem. Sci., 15 (2020) 10392 - 10405

International Journal of

ELECTROCHEMICAL

SCIENCE

WWW.electrochemsci.org

\title{
Fabrication of Titanium Dioxide Nanotubes and their Photovoltaic Performance for Dye-sensitized Solar Cells
}

\author{
Montri Aiempanakit ${ }^{1}$, Vanida Lumpol ${ }^{2}$, Thanyarat Mangsup ${ }^{2}$, Narit Triamnak ${ }^{3}$, Jaran Sritharathikun ${ }^{4}$, \\ Cheewita Suwanchawalit ${ }^{2, *}$ \\ ${ }^{1}$ Department of Physics, Faculty of Science, Silpakorn University, Sanam Chandra Palace Campus, \\ Nakhon Pathom, Thailand 73000 \\ ${ }^{2}$ Department of Chemistry, Faculty of Science, Silpakorn University, Sanam Chandra Palace Campus, \\ Nakhon Pathom, Thailand 73000 \\ ${ }^{3}$ Department of Materials Science and Engineering, Faculty of Engineering and Industrial Technology, \\ Silpakorn University, Sanam Chandra Palace Campus, Nakhon Pathom, Thailand 73000 \\ ${ }^{4}$ National Electronics and Computer Technology Center (NECTEC), Pathum Thani, Thailand 12120 \\ *E-mail: suwanchawalit_c@su.ac.th
}

doi: $10.20964 / 2020.10 .43$

Received: 23 April 2020 / Accepted: 8 August 2020 / Published: 31 August 2020

$\mathrm{TiO}_{2}$ nanotubes (TNTs) were prepared by the electrochemical anodization method using titanium thin films deposited on indium tin oxide (ITO) substrates by the DC magnetron sputtering technique. The effect of voltage $(20-40 \mathrm{~V})$ and amount of ammonium fluoride $\left(\mathrm{NH}_{4} \mathrm{~F}\right)(0.4-1.4 \mathrm{wt} \%)$ were investigated. The fabricated TNTs were characterized by field emission scanning electron microscopy (FE-SEM), X-Ray Diffraction (XRD), X-ray Photoemission spectroscopy (XPS), and FourierTransformed Infrared Spectrophotometry (FT-IR) techniques. XRD pattern data exhibited anatase phase when TNTs were annealed at $400^{\circ} \mathrm{C}$ for $3 \mathrm{~h}$. The XPS results revealed complement of Ti, O, F, Sn, In and $\mathrm{C}$. The FT-IR spectrum exhibited the characteristic bands of the $\mathrm{TiO}_{2}$ which indicate the Ti-O stretching mode. The average diameter and length of TNTs depend on ammonium fluoride, water and voltage and the optimal conditions were found to be $0.8 \mathrm{wt} \%$ ammonium fluoride, and voltage at $30 \mathrm{~V}$. The obtained TNTs have an averaged diameter of $38 \mathrm{~nm}$ and length of $763 \mathrm{~nm}$. For dye-sensitized solar cells (DSSCs) application, ruthenium complex (N719) was used as a sensitizer in this work. The energy conversion efficiency $(\eta)$ of TNTs was also evaluated.

Keywords: $\mathrm{TiO}_{2}$ nanotubes, Electrochemical anodization method, Dye-sensitized solar cell, N719 ruthenium-based dye, Photovoltaic performance

FULL TEXT 
(C) 2020 The Authors. Published by ESG (www.electrochemsci.org). This article is an open access article distributed under the terms and conditions of the Creative Commons Attribution license (http://creativecommons.org/licenses/by/4.0/). 